\title{
The Influence upon Algal Cells of an Alteration in the Hydrogen Ion Concentration of Sea Water.
}

\author{
By
}

W. R. G. Atkins, O.B.E., Sc.D., F.I.C.,

Head of the Department of General Physiology at the Plymouth Laboratory.

WHEN/studying the hydrogen ion concentration of algal cells it was thought desirable to see whether an increase in the alkalinity of the water had any influence upon the reaction of the cell sap. With normal sea water at $\mathrm{pH} 8 \cdot 2$ the algæ examined were at about $\mathrm{pH} 7$. When subjected to an approximate correction for salt error Ulva latissima L., was at $\mathrm{pH} 6.9$ and Ceramium rubrum at $\mathrm{pH} 7 \cdot 1$.

It had previously been ascertained that when Ulva was exposed to sunlight in a jar of sea water it abstracted so much carbonic acid as to render the water as alkaline as $\mathrm{pH} 9 \cdot 7$. This seemed a suitable method for increasing the alkalinity with the least possible change in the constituents of the sea water. Accordingly specimens of Ceramium growing on Fucus serratus were gathered and one was placed in a glass jar of sea water at $\mathrm{pH} 8.2$; Ulva was arranged round and over it in a single sheet so that no portion of the Ceramium was exposed directly to sunlight. The water rose to $27^{\circ} \mathrm{C}$. when insolated. Ulva may be kept for a month or more with daily exposure to intense sunlight and remains uninjured.

Before exposure the cells of Ulva, Ceramium, and of Vorticella epiphytic on the latter, stained very rapidly with neutral red, which tinges sea water faintly yellow, but showed no trace of colour with brom cresol purple. The latter gives its full blue in sea water, and ceases to be blue about $\mathrm{pH} 6$, changing to clear yellow at $\mathrm{pH} 5 \cdot 4$. Since the cells are at about $\mathrm{pH} 7$ the colour should have shown up as blue if any had penetrated. Normal cells of these algæ are therefore permeable to neutral red and impermeable to brom cresol purple.

After twenty-five minutes, wafer drawn from round the Ceramium was found to be at $\mathrm{pH} 9 \cdot 4$, giving a good blue with thymolphthalein and with thymol sulphone phthalein. On examining under the microscope it was seen that the Vorticella were still motile. These and the Ceramium cells behaved as before towards the two indicators, and were therefore still normal.

The plant, together with an unstained control, was then arranged 
behind the Ulva screen as before and was examined again at 6.15 p.m., after two and a half hours. Owing to the less intense illumination the water was then at $\mathrm{pH} 9 \cdot 2$. The Vorticellce were still all quite motile, though stained deep red from previous exposure to neutral red. These and the Ceramium were kept in sea water at $\mathrm{pH} 8.2$ tinged blue with brom cresol purple, and no penetration was observed inside ten minutes.

On keeping in the dusk for three hours it was noticed that some of the Vorticellce were dead on the two pieces of Ceramium exposed to high alkalinity, but most of them were active, as were all on the unexposed control. The exposed pieces of Ceramium were now stained blue at the tips and adjacent cortical cells, whereas the unexposed control remained perfectly colourless. On changing the water the blue colour diffused out to a considerable extent. It is clear that sea water at $\mathrm{pH} 9 \cdot 4$ has had an effect upon the permeability of the cells.

On allowing to stand overnight with very dilute neutral red the control Ceramium was stained throughout, whereas the treated pieces were nearly colourless at the tips, and in many of the cortical cells of the main axis, the large central cells of which were, however, stained deeply as in the control. The Vorticellce were now nearly all dead and colourless in the treated pieces, but quite active though deeply stained in the control. On placing in brom cresol purple the treated portions, which were only slightly tinged with neutral red, became blue, but not as intense a colour as before. Scarcely any stain was visible in the Vorticella.

Thus the alteration in permeability induced by water at $\mathrm{pH} 9 \cdot 4$ has not the nature of a reversible change, at least with the duration of treatment tried, viz. two and a half hours as a minimum. It has sufficed to render the cells quite permeable to the normally non-penetrating brom cresol purple and to permit the diffusion outwards of neutral red; in other words, it has killed the Ceramium cells which were in direct contact with the water, and the Vorticellee though more resistant died also.

There is accordingly a difference between its action upon the plant and animal cells, and even between the cells at the tips of the Ceramium branches and those further down, which are of greater age. A physiological axial gradient is seen to exist. Such gradients have been studied by Child (1916 onwards) in a series of papers on hydrozoa and algæ, and it has been demonstrated, by means of potassium permanganate acting on the former, that the rate and amount of reduction decrease basipetally. The more actively reducing portions are those most easily oxidised, and they are apparently the most sensitive to the action of alkalis also.

As already mentioned, Ulva can endure even direct exposure to sunlight and the resulting high alkalinity and remain living and healthy for considerable periods. It seems therefore that the distribution of these plants on the sea-shore must be to some extent limited by their capability 
to survive changes in alkalinity. Even though in rock-pools the writer has failed to observe a higher value than $\mathrm{pH} 8 \cdot 57$, higher values may probably be found, and in fresh water where the buffer action is very slight $\mathrm{pH} 9 \cdot 0$ has been observed in a pond. In any case Gail (1919) has shown that Fucus evanescens never grows in tide pools or where Ulva is found in any considerable quantity, and furthermore that the growth of young plants is very much inhibited in sea water at $\mathrm{pH} 8 \cdot 4$, and almost completely ceases at $\mathrm{pH} 8 \cdot 6$.

Considerable changes in $\mathrm{pH}$ value may be observed within a few minutes in the water close to the filament of an insolated green alga. In fresh water a good blue, indicating about $\mathrm{pH} 9$, was observed around such a filament while the general colour of the indicator, thymol blue, was yellow as given by $\mathrm{pH} 8 \cdot 2$ or less. These localised changes in $\mathrm{pH}$ value would suffice, for instance, to make it impossible for a sensitive epiphyte to develop in such a situation.

\section{SUMMARY.}

Sea water originally at $\mathrm{pH} 8.2$ became as alkaline as $\mathrm{pH} 9 \cdot 4$ by the photosynthetic action of Ulva in removing carbonic acid. This degree of alkalinity did not prove injurious to Ulva, but exposure to it for two and a half hours at $27^{\circ} \mathrm{C}$. sufficed to increase the permeability of the superficial cells of Ceramium rubrum irreversibly and fatally. Similar though less rapid changes brought about the death of numerous Vorticella epiphytic on Ceramium. The criteria for living cells were permeability to neutral red and impermeability to brom cresol purple. Dead cells do not retain neutral red specifically and are permeable to brom cresol purple.

It is suggested that the above facts have a bearing upon the distribution of these and similar algæ upon the shore.

\section{REFERENCES.}

ChIld, C. M. 1916. Axial susceptibility gradients in algæ. Bot. Gaz., 62.

—. 1919. A study of susceptibility in some Puget Sound algæ. Publ. Puget Sound Biol. Sta., 2, 249.

- 1921. The axial gradients in Hydrozoa, IV. Biol. Bull. 41, No. 2.

GAIL, F. W. 1919. Hydrogen ion concentration and other factors affecting the distribution of Fucus. Publ. Puget Sound Biol. Sta., 2, 287. 